\title{
Analyzing Pre-service Teachers' Educational Philosophy Preferences, Curriculum Design Orientation, and Epistemological Beliefs with Structural Equation Model
}

\author{
Caner Börekci* \\ Şehit Prof. Dr. Ilhan Varank Science and Art Centre, Ballkesir, Turkey \\ ORCID: 0000-0001-5749-2294 \\ Nihat Uyangör \\ Necatibey Faculty of Education, Ballkesir University, Ballkesir, Turkey \\ ORCID:0000-0002-4814-3866
}

\begin{tabular}{l}
\hline \hline Article history \\
\hline Received: \\
26.06 .2020 \\
Received in revised form: \\
14.02 .2021 \\
\\
Accepted: \\
18.02 .2021 \\
Key words: \\
\hline Educational philosophy \\
preferences, \\
Curriculum design orientation, \\
Epistemological beliefs
\end{tabular}

Epistemological beliefs
The purpose of this study is to examine the partial mediating effect of epistemological beliefs in the correlation between preferences towards educational philosophy and the curriculum design approach of preservice teachers. For this purpose, pre-service teachers' educational philosophy preferences, curriculum design orientation, and epistemological beliefs have been analyzed, and a model has been developed. Three different instruments have been implemented to randomly chosen 568 pre-service teachers in several departments in Necatibey Faculty of Education of Balıkesir University in Turkey. In the analyzing process, first, a measurement model has been developed, and compatibility of the model with real data has tested, second, Pearson correlation coefficients have calculated, and the levels have defined, third, $t$ values have calculated for the direct effect between preference for educational philosophies and curriculum design orientation preference, and at last, the epistemological beliefs have added to the model, and the moderating role on them has calculated. Based on findings, it can be concluded that from the pre-service teachers perspective; there is a positive correlation between widely accepted educational philosophies, and curriculum design orientations and there is a positive correlation between epistemological beliefs in effort and contemporary educational philosophies. In line with that, there is a positive correlation between epistemological belief in effort, and student-oriented design and problemoriented design. Besides educational philosophy preferences $(\mathrm{P}=.14)$ and epistemological beliefs $(\mathrm{P}=.18)$ have a separate effect on curriculum design orientation, and epistemological beliefs (CIs $=-.029 \sim .588$ ) do not have a mediating role on the effect of educational philosophy preferences.

\footnotetext{
*Correspondency: canerborekci@hotmail.com
} 


\section{Introduction}

Education is a process of constructing a way for a learner's purposeful changes throughout their own lives and the desired situations require a certain design to be constructed through education (Ertürk, 2013). Effectiveness/efficiency of education, meeting the needs/expectations of the society, and those of a person can be provided within the framework of a specific plan and program, in other words, education programs. Ertürk (2013) defines education program as the planning of the educational settings that the program was implemented in by organizing the educational experiences to train the students. Similarly, Sönmez (2009) defines education programs, which have specific objectives to be observed in a learner in the form of behavior changes, as a vivid pattern that includes regular teaching and assessing process.

The training experiences and patterns organized within the framework of the programs are shaped according to the essentials on which the programs are based and the approach of the implementers. Education programs are based on philosophical, historical, psychological, and social bases (cultural, political, and economic foundations can also be included in the social basis). Individuals' approach to the program reflects their perceptions, values, and knowledge. This approach reflects the holistic structure of the program (its philosophy, historical, psychological, and social view) and the theories and practices which the program is based on (Ornstein \& Hunkins, 2014). The program design is the task of determining what elements a program will consist of and what kind of relationship will take place amongst these elements. With the program design studies, the main framework of the program is tried to be determined (Şeker, 2019). The main purpose of the program design is to enable the student to learn, and program design is a complex process and requires many decisions to be made at various levels (Berkant, 2020).

Ertürk (1988) considered the philosophy of education, which is among the essentials of the program, both as a product and a process. The educational philosophy as a product covers the values and assumptions based on guiding educational activities and evaluating practices. The philosophy of education as a process defines education as a top-down process by constantly evaluating the values and assumptions that arise. This definition implies that the philosophy, which the program is based on, is observed at every stage of the program. Similarly, Ornstein and Hunkins (2014) place philosophy in the centre of the program and declare that the philosophy of a school and its staff affect the objectives, content, and structure of the school's program. The philosophy, which education is based on, helps to determine the reason for the existence of the school, the importance of the courses offered, the way students learn, and the methods and materials to be used. According to Ornstein and Hunkins (2014), educational philosophy determines the aims of education, appropriate content, learning, and teaching environment as well as processes. Besides, philosophy provides a basis for choosing books to read, the way to use them, the amount of homework that will be given, the ways of assessing the students and the ways of using these exam results, along with the ways to define the importance of lessons and topics. Similarly, Demirel (2020) expresses that the philosophy of education has an important place in curriculum development activities as it reflects the way of thinking, opinions, beliefs and affects the target and the content of a school. Thereupon educational philosophy can be defined as a type of applied philosophy based on different philosophical methods such as wondering, questioning, and guessing (Çüçen, 2018). Educational philosophy analyses the concepts related to education and focuses on certain variables that direct education and helps shape the aims of education (Cevizci, 2014) as well. In fact educational philosophies consist of four movements: perennialism, essentialism, progressivism, and reconstructionism (Demirel, 2020; Ornstein \& Hunkins, 2014; Seagell \& 
Willson, 2004).

Educational philosophy is the foundation of the program's design focus and elements. In the design process of the curriculum, the elements of the curriculum (goal, content scope, learning-teaching process, and evaluation) are consistently structured and organized. A subject, learner, or a problem can be the design focus of the program (Ornstein \& Hunkins, 2014). Subject-oriented curriculum designs are the most common form of designs (Demirel, 2020). In this design approach, the content is in the centre; learning outcomes are organized by content. The subject-oriented curriculum is classified as subject design, discipline design, broad-fields design, correlation design, and process design (Ünsal \& Korkmaz, 2017). In the subject-oriented design, the content is gradually arranged from simple to complex, and the teaching process takes place by the direct expression of the subjects in the textbook or learning the subjects by the student. Learner-oriented designs are shaped around student needs, interests, and goals. The dominant belief is that students have different characteristics features, and hence the process is realized through the student's experiences (Demirel, 2020). Learner-oriented designs are grouped as child-oriented designs, experience-oriented designs, romantic (radical) designs and humanistic designs. Problem-oriented designs are developed to strengthen the cultural and traditional values of societies, as well as to point out the unmet needs of society. (Demirel, 2020). This approach teaches students how to look at a problem and how to formulate a solution and prepares students for overcoming the everyday problems they may encounter in real life. Problem oriented designs are categorized as life-situations design, core design, social problems design, and re-constructionist design.

The curriculum design is mainly the study of making the elements of the curriculum meaningful for students, teachers, and society in accordance with the philosophy that it is based on. The effectiveness and success of the curriculum also depends on the practitioner's (teacher's) perspectives and beliefs (Olson, 1981; Cheng, 1994; Bulut \& Arslan, 2010; Han, 2013; Jenkins 2020). The source of decisions regarding the program's objectives, content, organization, teaching strategies, learning activities, and evaluation of instruction is teachers' beliefs about the design of the curriculum (Cheung \& Ng; 2000).

Epistemology is one of the most essential disciplines of philosophy that makes inquiries about the nature of knowledge (Arslan, 2017; Yazic1, 2016). Epistemology (i.e philosophy of knowledge) is a branch of philosophy like educational philosophy and explains how an individual, acquires knowledge, constructs this knowledge and subjective perspectives, alongside the formation of the learning processes. Epistemology is formed by the combination of the words episteme and logos. While the word episteme means knowledge or science, the word logos means thought or reason, or a word (Özemre, 2011). According to Moser (2020), studies on the nature of knowledge constitute the area of the interest in epistemology. As reported by Schommer (1994), epistemological understanding refers to the philosophical beliefs about nature, acquisition, source, scope, and limits of knowledge. This belief reflects the perspective of the individual about what the knowledge is, how this knowledge is acquired, taught and produced, and differs according to the perspective that centred in teaching practices (Tezci \& Uysal, 2004).

The related literature indicates that teachers' preferences towards educational philosophy, curriculum design orientations, and epistemological beliefs have an impact on teaching and learning activities. It can be concluded that it then would be meaningful to examine the correlations among the trend towards educational philosophy, the curriculum design approach, and epistemological belief. Belief can be expressed as a state of sincere attachment 
to thought. Cevizci (2015) explains belief as to the mental state of a person who is convinced of the correctness of a proposition. Individual acceptance of nature, accuracy, source, structure and acquisition of knowledge constitutes the epistemological belief. (Hofer, 2001). Although it is known that the epistemological beliefs are related to the philosophy of education (Biçer, Er \& Özel, 2013, Kürşad, 2015; Kanadlı \& Akbaş, 2015; Kaya \& Ekici, 2015; Erdamar \& Alphan 2015; Yenice, 2015;Tezci, Erdener \& Satıc1, 2016; İra \& Geçer, 2017; Aslan, 2017; Dursun Sürmeli \& Ünver, 2017, Terzi \& Uyangör, 2017), and that there is a relationship between the philosophy of education and the curriculum design approach (Baş, 2015; Kozikoğlu \& Uygun, 2018; Aslan, 2018; Baş \& Sentürk, 2019), it is understood taking a glance at the relevant literature that the relationships of all of these three variables have not yet been studied .

Teachers' beliefs and understandings about the nature of knowledge and curriculum design begin to take shape before starting their profession (Flores \& Day, 2006; Pajares, 1992). In this case, the importance of teacher education emerges. Philosophical perspectives and epistemological beliefs of students in teacher education hold the key importance in determining the curriculum design (Doğanay, 2011; D'souza, 1992). In this context, examining the relationship between faculty of education students' epistemological beliefs, philosophical tendencies towards education and their understanding of curriculum can provide important indicators for policymakers, curriculum experts, lecturers, and researchers in the field in regard to the preparation and implementation of more qualified teacher education programs.

The purpose of this research is to try to reveal a structural model of the correlations between these three variables. Also, it is aimed to examine the partial mediating role of epistemological belief in the correlation between the trend towards educational philosophy and the curriculum design approach preferences. Accordingly, the answers to the following questions were sought in the research.

(1) What are the pre-service teachers' tendencies towards educational philosophies, curriculum design approaches, and epistemological beliefs?

(2) Is there a correlation between the tendency towards educational philosophies, educational program design understanding, and epistemological beliefs?

(3) Is there a mediating role of epistemological beliefs on the correlation between the trend towards educational philosophies and the curriculum design approach?

\section{Methodology}

This research is a correlational survey, which is one of the descriptive research types and tries to define the correlations between the variables as they are. Correlational survey models aim to determine the presence or degree of change between two or more variables together (Karasar, 2013). In this study, the correlation between pre-service teachers' tendency towards education philosophy, curriculum design approach, and epistemological beliefs will be examined.

\section{Participants}

The study group of the research is prospective teachers $(\mathrm{N}=568)$ who attend 3rd and 4th grades at the Faculty of Education in Balıkesir University in 2018-2019 academic year. Random sampling method was used to determine the participants. $78.7 \%(\mathrm{n}=447)$ of the 
participants are women and 21.3\% $(\mathrm{n}=121)$ are men. Departments of the participants are $\mathrm{n}=$ $281(49.5 \%)$ in basic sciences and $n=287(50.5 \%)$ in social sciences.

\section{Data collection tools}

In the study, "Preference for Educational Philosophies Scale" to determine the tendencies of pre-service teachers regarding educational philosophies, "Epistemological Beliefs Scale" to determine the levels of epistemological beliefs, and "Curriculum Design Orientations Preference Scale" to determine their preference were implemented. Information about the data collection tools used is presented below.

\section{Preference for Educational Philosophies Scale}

Preference for Educational Philosophies Scale developed by Uyangör, Şahan, Atıcı and Börekci (2016) was used to determine the tendencies of prospective teachers participating in this study. The scale which has four sub-dimensions consists of 36 items, 9 items for each dimension. The scale is a 5-point Likert type and participants were asked to give a value of 1 (strongly disagree) to 5 (strongly disagree) to the statements in the scale items. The subdimensions of the scale are essentialism, perennialism, progressivism and re-constructionism. Cronbach's alpha coefficient values of the sub-dimensions; essentialism is .72, perennialism .67 , progressivism .88 and re-constructionism .86 , while the total value of the scale is .84 . In this study, Cronbach's alpha coefficient values; essentialism .77, perennialism .71, progressivism .77, re-constructionism .81 , and .77 for the entire scale.

\section{Curriculum Design Orientations Preference Scale}

Curriculum Design Orientations Preference Scale, developed by Baş (2013), determines pre-service teacher preferences. The scale, which has three sub-dimensions, consists of 30 items, 10 items for each dimension. The scale is a 5-point Likert type and participants were asked to give a value of 1 (strongly disagree) to 5 (strongly disagree) to the statements in the scale items. The sub-dimensions of the scale are subject-oriented design, learner-oriented design, problem-oriented designs. Cronbach's alpha coefficient values of the sub-dimensions are; subject-oriented design is .89, learner-oriented design .89, problemoriented designs .87. In this study, Cronbach's alpha coefficient values are; subject-oriented design is .71, learner-oriented design .76, problem-oriented designs .79, and .72 for the entire scale.

\section{Epistemological Beliefs Scale}

The epistemological beliefs scale developed by Schommer (1990) for university students, adapted to Turkish by Deryakulu and Büyüköztürk (2005). The Turkish version of the scale consists of 35 items in three sub-dimensions. In this study, the 29-item version of the scale, which was restructured by Aydın, Selçuk, Çakmak, and İlğan (2017), was used. The first sub-dimension "effort" has 15 items, the second sub-dimension "ability" has 8 items and the last sub-dimension "single truth" has 6 items. The scale is a 5-point Likert type and participants were asked to give a value of 1 (strongly disagree) to 5 (strongly disagree) to the statements in the scale items. Cronbach's alpha coefficient values of the sub-dimensions are; effort is .88 , ability .88 , single truth .85 . In this study, Cronbach's alpha coefficient values are; effort is .73 , ability .78 , single truth .78 , and .78 for the entire scale. 


\section{Data gathering procedure}

First, the purpose of the study was explained to prospective teachers, then the instruments applied to the participants that were volunteers. Implementation takes two class hours.

\section{Data analysis}

The correlation between preference for educational philosophies, curriculum design orientations preference and the epistemological beliefs were analysed in six steps. (1) The normality assumption of the data was analysed. (2) Descriptive statics about variables were calculated. (3) The measurement model was developed and compatibility of the model with real data was tested. (4) Pearson correlation coefficients were calculated and the levels were defined. For positive correlations, if the correlation coefficient between .01 and .29 it is a low level, .30 and 49, it is a moderate level, if higher than .50, then it is a high-level correlation. For negative correlations, if the correlation is between -.01 and -.29, it is a low level, if between --.30 and .49, it is a moderate level, on the condition that it is smaller than -.50 , it is a high-level correlation (Cohen, 1988). (5) $t$ values were calculated for the direct effect between preference for educational philosophies and curriculum design orientation preference. (6) The epistemological beliefs were added to the model and the moderating role of it was calculated. Then bootstrapping analysis was performed for direct and indirect effects. AMOS Graphics 21 and IBM SPSS Statistics 21 software were used for analysis.

\section{Findings}

First of all, the normality assumptions of the data were calculated. For this purpose, mean, mode, median, skewness, and kurtosis values were examined. It can be concluded that if mean, median, and mode values are equal in data series, the data were distributed normally around the measures of central tendency. If mean, median, and mode values are not equal, then z scores of skewness and kurtosis will be calculated for normality (Büyüköztürk, 2011). In this case mean, median and mode values are even close to each other, and $\mathrm{Z}$ scores of skewness and kurtosis is between $\pm 1,96$ so it can be concluded that the data distributed normal and parametric test could be applied (Field, 2016). Preference for educational philosophies scores, curriculum design orientations preference scores and the epistemological beliefs scores are distributed normally (Table 1).

Table 1. Test of normality

\begin{tabular}{llllll}
\hline & Mean & Mode & Median & $Z_{\text {Skewness }}$ & $Z_{\text {kurtosis }}$ \\
\hline Essentialism & 2.29 & 2.22 & 2.22 & .793 & .766 \\
Perennialism & 3.13 & 3.11 & 3.11 & .022 & -.061 \\
Progressivism & 4.43 & 4.45 & 4.44 & -.804 & .761 \\
Re-Constructionism & 4.39 & 4.50 & 4.44 & -.650 & .303 \\
Subject-oriented design & 3.10 & 3.00 & 3.10 & .364 & .408 \\
Learner-oriented design & 4.17 & 4.00 & 4.20 & -.331 & .704 \\
Problem-oriented designs & 3.96 & 3.80 & 3.90 & -.198 & .276 \\
Effort & 4.12 & 4.13 & 4.13 & -.138 & .157 \\
Ability & 2.07 & 2.00 & 2.00 & .579 & .537 \\
Single truth & 2,39 & 2.33 & 2.33 & .180 & -.095 \\
\hline
\end{tabular}

After the test of normality, the compatibility of the model with real data was tested (Figure 1). In the model, preference for educational philosophies, curriculum design orientations preference, and the epistemological beliefs were defined as latent variables and the scores of 
sub-dimensions were defined as observed variables. Observed variables were Essentialism, Perennialism, Progressivism, Re-Constructionism, Effort, Ability, Single truth, Subjectoriented design, Learner-oriented design, and Problem-oriented designs. These observed variables enable us to measure latent variables. In this way, a measurement model was developed with three latent and ten observed variables. Path diagram is illustrated in figure 1 . When fit indices of the measurement model were analysed; Chi-Square value is significant $(\mathrm{x} 2=137.51, \mathrm{df}=568, \mathrm{p}=0.00)$. Chi-square and degree of freedom rate is $\mathrm{x} 2 / \mathrm{df}=2.35$. The fit indices of the model were NFI $=.96, \mathrm{GFI}=.95, \mathrm{CFI}=.95, \mathrm{RMSEA}=.06$, and is calculated: SRMR $=.04$. These indices shows that the model is convenient (Marsh, Balla \& McDonald, 1988; Sümer, 2000; Hooper, Coughlan, Mullen, 2008; Y1lmaz \& Çelik, 2009; Schumacher \& Lomax, 2010; Büyüköztürk, Çokluk-Bökeoğlu \& Şekercioğlu, 2012).

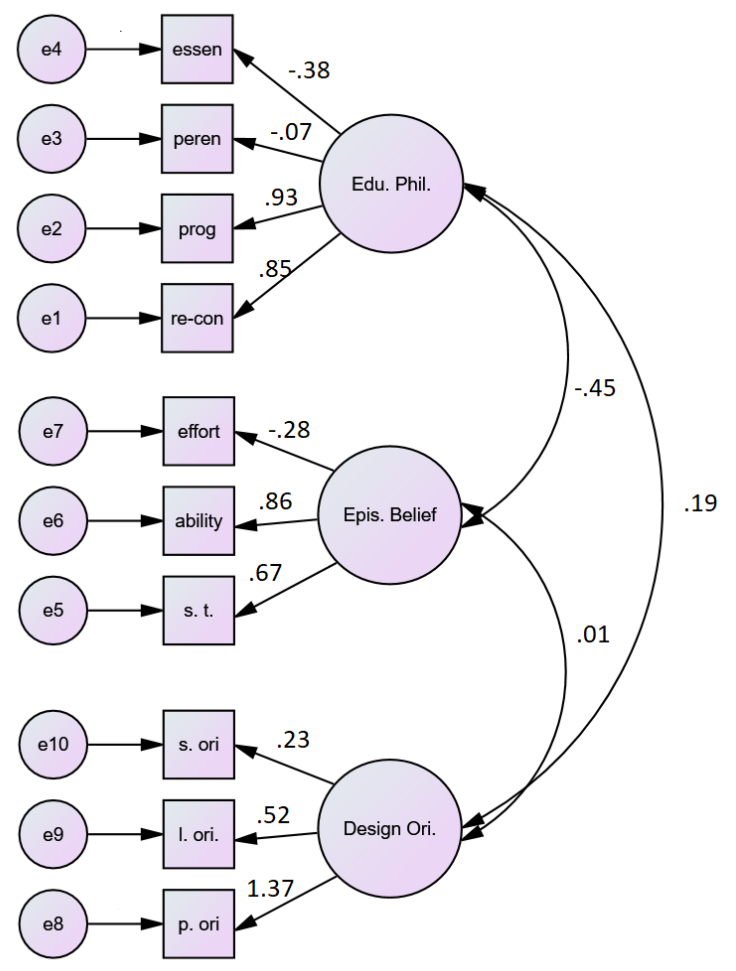

Figure 1. Measurement Model

Table 2 illustrates means, standard deviations, and the correlations. It can be concluded that the pre-service teachers' re-constructivism and progressivism preferences are dominant preferences in educational philosophies. Learner-oriented design preference is more preferred in design orientations and belief in effort is intensively found in epistemological beliefs. Correlations between educational philosophy preferences were examined, it was observed that, there is a positively high correlation between essentialism and perennialism $(r=.631, p$ $<.05)$, there is a positively high correlation between progressivism and re-constructivism $(\mathrm{r}=$ $.777, \mathrm{p}<.05)$, there is a negatively moderate correlation between essentialism and progressivism $(\mathrm{r}=-.336, \mathrm{p}<.05)$, and there is a negatively low correlation between essentialism and re-constructivism $(\mathrm{r}=-.262, \mathrm{p}<.05)$. Correlations between curriculum design orientations preferences were examined, it was observed that, there is a positively low correlation between subject-oriented design and problem-oriented design $(r=.206, p<.05)$, there is a positively moderate correlation between learner-oriented design and problemoriented design $(\mathrm{r}=.426, \mathrm{p}<.05)$. Correlations between epistemological beliefs were examined, it was observed that there are negatively low correlations between effort and single 
truth $(r=-.244, p<.05)$, and between ability and single truth $(r=-.175, p<.05)$. When the correlations between the sub-dimensions were taken in to account; it was observed that, there is a positively moderate correlation between essentialism and subject-oriented design $(\mathrm{r}=$ $.433, \mathrm{p}<.05)$, there is a negatively low correlation between essentialism and learner-oriented design $(\mathrm{r}=-., 246, \mathrm{p}<.05)$, there is a negatively low correlation between essentialism and effort $(r=-., 099, p<.01)$, there is a positively moderate correlation between essentialism and ability $(\mathrm{r}=.460, \mathrm{p}<.05)$, and there is a positively moderate correlation between essentialism and single truth $(\mathrm{r}=.441, \mathrm{p}<.05)$. Correlations between sub-dimensions were examined and it was observed that, there is a positively moderate correlation between perennialism and subject-oriented design $(\mathrm{r}=.469, \mathrm{p}<.05)$, there is a negatively low correlations between perennialism and learner-oriented design $(\mathrm{r}=-.109, \mathrm{p}<.01)$, there is a positively low correlation between perennialism and subject-oriented design $(\mathrm{r}=.108, \mathrm{p}<.01)$, there is a positively moderate correlation between perennialism and ability $(\mathrm{r}=.353, \mathrm{p}<.05)$, and there is a positively moderate correlation between perennialism and single truth $(\mathrm{r}=.456, \mathrm{p}<.05)$.

Table 2. Means, standard deviations and the correlations.

\begin{tabular}{|c|c|c|c|c|c|c|c|c|c|c|c|c|}
\hline & $x$ & $S d$ & 1 & 2 & 3 & 4 & 5 & 6 & 7 & 8 & 9 & 10 \\
\hline Essentialism & 2.29 & .65 & 1 & $.631^{* *}$ & $-.336^{* *}$ & $-.262^{* *}$ & $.433^{* *}$ & $-.246^{* *}$ & .011 & $-.099^{*}$ & $.460^{* *}$ & $.441^{* *}$ \\
\hline Perennialism & 3.13 & .56 & & 1 & -.030 & -.003 & $.469^{* *}$ & $-.109^{*}$ & $.108^{*}$ & .003 & $.353^{* *}$ & $.456^{* *}$ \\
\hline Progressivism & 4.43 & .44 & & & 1 & $.777^{* *}$ & -.073 & $.484^{* *}$ & $.370^{* *}$ & $.422^{* *}$ & $-.239^{* *}$ & $-.166^{* *}$ \\
\hline $\begin{array}{l}\text { Re- } \\
\text { Constructionism }\end{array}$ & 4.39 & .46 & & & & 1 & -.014 & $.383^{* *}$ & $.426^{* *}$ & $.424^{* *}$ & $-.188^{* *}$ & $-.198^{* *}$ \\
\hline $\begin{array}{l}\text { Subject-oriented } \\
\text { design }\end{array}$ & 3.10 & .45 & & & & & 1 & -.022 & $.206^{* *}$ & $.100^{*}$ & $.244^{* *}$ & $.373^{* *}$ \\
\hline $\begin{array}{l}\text { Learner-oriented } \\
\text { design }\end{array}$ & 4.17 & .39 & & & & & & 1 & $.544^{* *}$ & $.404^{* *}$ & $-.282^{* *}$ & $-.213^{* *}$ \\
\hline $\begin{array}{l}\text { Problem-oriented } \\
\text { designs }\end{array}$ & 3.96 & .35 & & & & & & & 1 & $.377^{* *}$ & -.080 & -.0371 \\
\hline Effort & 4.12 & .36 & & & & & & & & 1 & $-.244^{* *}$ & $-.175^{* *}$ \\
\hline Ability & 2.07 & .64 & & & & & & & & & & $.512^{* *}$ \\
\hline Single truth & 2,39 & .64 & & & & & & & & & & 1 \\
\hline
\end{tabular}

After the correlations were analysed, $\mathrm{t}$ value was calculated to test the significance of the direct effect between preference for educational philosophies and curriculum design orientations preference. Essentialism, perennialism, progressivism, and re-constructionism were observable variables of educational philosophy preferences. Subject-oriented design, learner-oriented design, and problem-oriented designs were observable variables of design orientations of teacher candidates. As clearly seen in Figure-2, it was found that the correlation between them was significant at the level of .05 and the path coefficient was $\mathrm{P}=$ .25 .

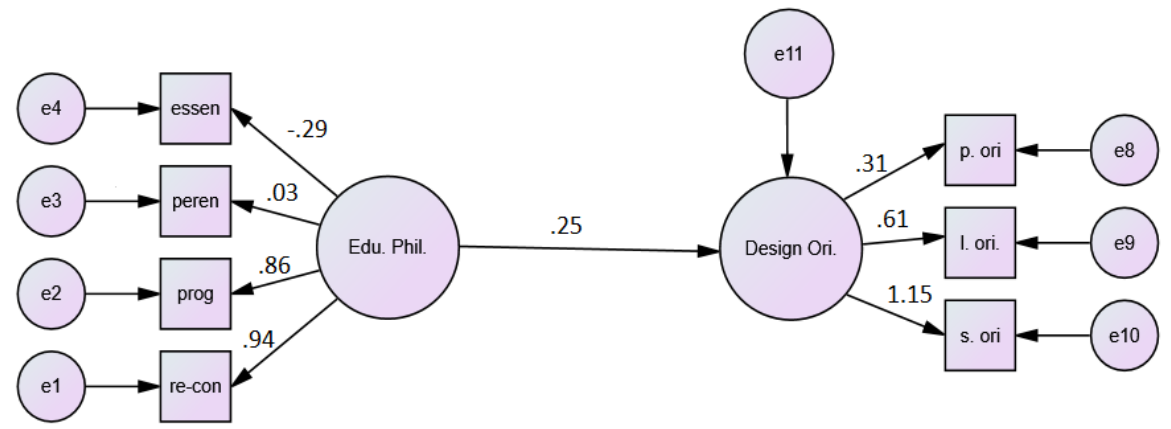

Figure 2. Structural model of preference for educational philosophies and curriculum design orientations preference 
At the last stage of the analysis of the data, the epistemological belief was added as a mediator variable to the model between preference for educational philosophies and curriculum design orientations preference and the model containing the partial mediation relationship was tested. As a result of the path analysis, the fit indices of the model were found to be sufficient. The model is as in Figure-3.

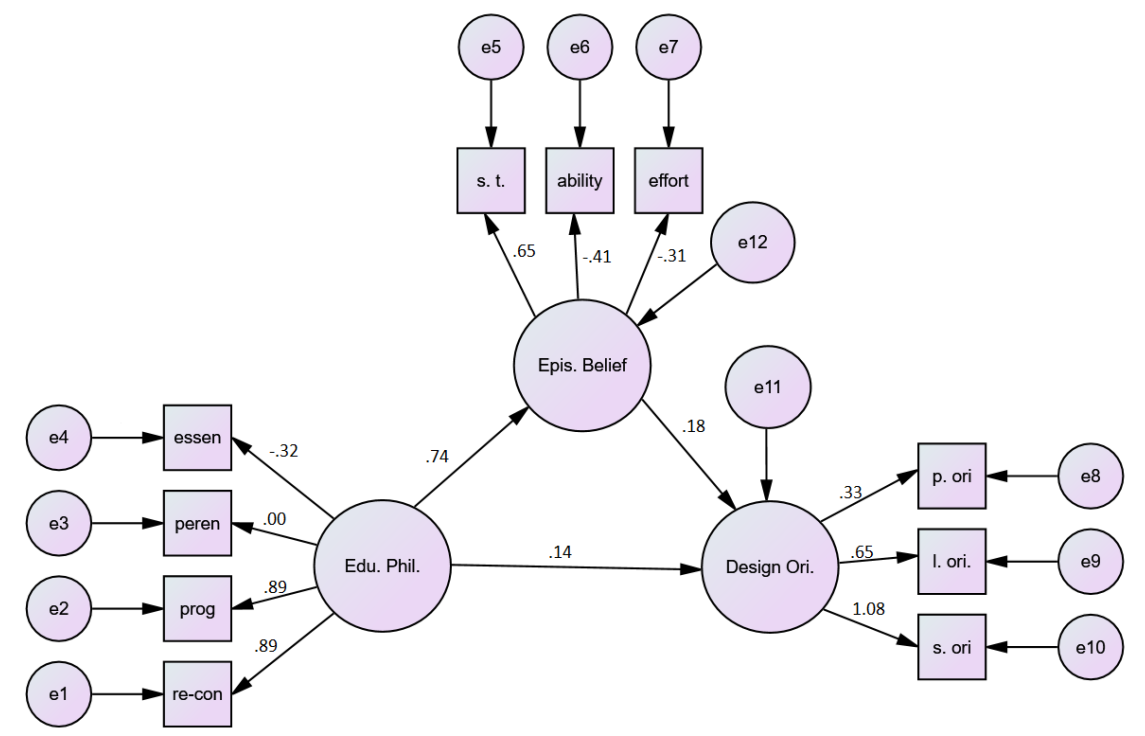

Figure 3. Structural model of preference for educational philosophies, curriculum design orientations preference, and epistemological beliefs

When fit indices of the measurement model were analysed; Chi-Square value is significant $\left(\mathrm{x}^{2}\right.$ $=323.43, \mathrm{df}=568, \mathrm{p}=0.00)$. Chi-square and degree of freedom rate is $\mathrm{x}^{2} / \mathrm{df}=.57$. The fit indices of the model were NFI $=.95, \mathrm{GFI}=.96, \mathrm{CFI}=.95, \mathrm{RMSEA}=.07$, and the calculation for is SRMR $=.03$. These indices shows that the model is convenient (Marsh, Balla \& McDonald, 1988; Sümer, 2000; Hooper, Coughlan, Mullen, 2008; Y1lmaz \& Çelik, 2009; Schumacher \& Lomax, 2010; Büyüköztürk, Çokluk-Bökeoğlu \& Şekercioğlu, 2012).

When Figure-2 and Figure-3 are examined together, it is seen that the direct effect of the preference for educational philosophies and curriculum design orientations preference is $\mathrm{P}=$ .25 , and if it is modeled as an intermediary in the effect of epistemological belief on the philosophy of educational design, it is $\mathrm{P}=.14$. This reduction in impact implies that epistemological belief may have a partial mediating effect between preference for educational philosophies and curriculum design orientations preference. Bootstrapping analysis was performed to determine the significance level of this effect. When the analysis is made, it is seen that the preference for educational philosophies does not have a statistically significant effect on the curriculum design orientations preference $(\mathrm{p}=.424)$. There should not be " 0 " between the estimates of the indirect effect, in other words, between the upper and lower values (CIs $=-.029 \sim .588$ ) (Hayes, 2009). In the analysis, the value of 0 is among the estimates of the indirect effect. From this point of view, it can be said that preference for educational philosophies affect curriculum design orientations preference, but epistemological beliefs do not have a partial mediating effect in this correlation (Table-3). 
Table 3. Bootstrapping Analysis for indirect effect

\begin{tabular}{lllll}
\hline $\begin{array}{l}\text { Independent } \\
\text { variable }\end{array}$ & $\begin{array}{l}\text { Dependent } \\
\text { variable }\end{array}$ & Mediator variable & $\begin{array}{l}\beta \text { Standardized indirect } \\
\text { effect }\end{array}$ & $\begin{array}{l}95 \% \text { confidence interval } \\
\text { mean } \\
\text { indirect effect min }- \text { max } \\
\text { values }\end{array}$ \\
\hline $\begin{array}{l}\text { preference for } \\
\begin{array}{l}\text { educational } \\
\text { philosophies }\end{array}\end{array}$ & $\begin{array}{l}\text { curriculum } \\
\text { design } \\
\text { orientations } \\
\text { preference }\end{array}$ & $\begin{array}{l}\text { epistemological } \\
\text { beliefs }\end{array}$ & $.74 \times .18=.133$ & $-.029 \sim .588$ \\
\hline
\end{tabular}

When the findings are briefly summarized; first the preservice teachers have preferred the generally accepted contemporary educational philosophies (progressivism and reconstructionism), and there are high-level positive relations among these tendencies; on the other hand, essentialism and perennialism, have been observed to be less accepted and negative correlations with contemporary approaches. Second, it was observed that teacher candidates adopt learner-oriented curriculum design approach more than problem-oriented and subject-oriented design approaches. Third, pre-service teachers' beliefs that learning depends on effort is higher than other beliefs, and negative low-level correlations were found between effort factor and ability and single truth. Fourth, there are positive correlations among contemporary educational philosophies (progressivism and re-constructionism) and, learner-oriented curriculum design orientation, problem-oriented curriculum design orientation and the belief that learning depends on effort. And last, it can be concluded that philosophical preferences and epistemological beliefs have separate effects on program design, epistemological beliefs have no mediating role on the effect of philosophical understanding.

\section{Discussion, Conclusion and Recommendations}

In this study, the correlations among preference for educational philosophies, curriculum design orientations preference and epistemological beliefs were analysed. When findings of the preference for educational philosophies were examined, progressivism and reconstructivism preferences were dominant preferences, there were positively high correlations between progressivism and re-constructivism, there were positively high correlations between essentialism and perennialism, and there were negative correlations between these two groups. These findings are similar to other research conducted with pre-service teachers regarding educational philosophy (Kumral, 2015; Uyangör vd., 2016; Hayırsever \& Oğuz, 2017; Y1lmaz, 2017; Kozikoğlu \& Erden, 2018; Aslan, 2018; Bingöl \& Kinay, 2018; Doğanay \& Sarı, 2018; Balcı \& Küçükoğlu,2019). As a result, it can be said that, with similar studies in the field, prospective teachers adopt contemporary educational philosophies. Findings of pre-service teachers' curriculum design orientations preference reveal that student-centred design is acknowledged more than problem-centred and subject-centred designs. Research findings of the current study are similar to studies conducted with preservice teachers by Bilgin and Aykaç (2016), Kozikoğlu and Uygun (2018), and Aslan (2018). In addition, Ünsal and Korkmaz (2017) stated that teachers adopted student-centred and problem-centred curriculum design orientations preference. When the epistemological beliefs of pre-service teachers are examined; negatively low correlations were determined between effort and ability, and effort and a single truth. Pre-service teachers' belief that learning depends on effort is higher than other beliefs. These findings are similar to other research conducted with pre-service teachers regarding epistemological beliefs (Biçer, Er \& Özel, 2013, Kürşad, 2015; Kanadlı \& Akbaş, 2015; Kaya \& Ekici, 2015; Erdamar \& Alphan 2015; Yenice, 2015;Tezci, Erdener \& Satıc1, 2016; İra \& Geçer, 2017; Aslan, 2017; Dursun 
Sürmeli \& Ünver, 2017). Likewise, similar results were revealed in research conducted by Karaman and Bakaç (2018) with teachers. On the other hand, Türkan, Aydın and Üner (2016) stated that pre-service teachers' epistemological beliefs are respectively single truth, ability and effort. Şekercioğlu and Yıldırım (2018) stated that the pre-service teachers' epistemological beliefs that learning depends on the effort are embraced more in the whole group, while the epistemological beliefs adopted differ according to the departments. When the correlation between pre-service teachers' preference for educational philosophies and curriculum design orientations preference were examined, there is a positively moderate correlation between essentialism and subject-oriented design, and between perennialism and subject-oriented design. There is a negatively low correlation between essentialism and learner-oriented design, and between perennialism and learner-oriented design. There is a positively moderate correlation between progressivism and learner-oriented design, between progressivism and subject-oriented design, between re-constructivism and learner-oriented design, and between re-constructivism and subject-oriented design. In other words, from preservice teachers' perspective; there is a positive correlation between widely accepted educational philosophies, and curriculum design orientations whereas there is a positive correlation between not-widely accepted educational philosophies and curriculum design orientations. Similar to this current study Kozikoğlu and Uygun (2018), and Aslan (2018) stated that the perspective of pre-service students' contemporary educational philosophies correlated with contemporary learning-teaching conceptions whereas traditional educational philosophies correlated with traditional learning-teaching conceptions. Additionally, Baş (2015) found similar findings whereas the correlation between traditional educational philosophies and traditional learning-teaching conceptions are more meaningful.

The findings indicated that there is a positive correlation between epistemological belief in effort and contemporary educational philosophies, and in line with that there is a positive correlation between epistemological belief about effort and student-oriented and problemoriented design. There is a positive correlation between ability, single truth, traditional educational philosophies and subject-oriented design. These findings are similar to studies of Lane (2015), Tezci et al. (2016).

This study has similar findings with the other studies conducted in the field, which compared two phenomena. However, this research compared three phenomena, educational philosophy preferences, curriculum design orientation, and epistemological beliefs. Furthermore, the effects of epistemological beliefs and educational philosophy preferences on curriculum design orientation were examined, and the mediating role of epistemological beliefs on the correlation between educational philosophy preferences and curriculum design orientation were analysed. It is concluded that educational philosophy preferences and epistemological beliefs have a separate effect on curriculum design orientation and epistemological beliefs do not have a mediating role on the effect of educational philosophy preferences. At the same time, findings indicate that pre-service teachers prefer contemporary educational philosophies, curriculum design orientations, and have epistemological beliefs accordingly. In conclusion, a the findings mentioned above demonstrate the source of educational philosophy preference, curriculum design orientation, and epistemological beliefs of pre-service teachers are based on learning- teaching conceptions that were implemented in their previous educational experiences (Belet \& Güven, 2011; Yenice, 2015; Tezci vd. 2016). It can be concluded that pre-service teachers' epistemological beliefs developed in the way toward constructivist education approach, which has been implemented since 2005 by Turkish Ministry of National Education, and pre-service teachers' awareness and preferences of educational philosophies, and curriculum design orientations take form during their 
undergraduate education.

Overall, the findings of the study are in concordance with those of other studies in the literature related with educational philosophies, curriculum design orientation and epistemological beliefs, and show that following educational philosophies and epistemological beliefs that are aligned with contemporary curriculum design orientations is common? (the sentence is not complete- please check). Needless to say, taking courses on educational philosophies as part of the undergraduate education will enhance the training process of pre-service teachers. It is possible to say that epistemological beliefs can be improved. Similarly, courses can be organized to enhance and improve pre-service teachers' perspectives on the nature of knowledge and acquiring knowledge. Instructors can be role models for prospective teachers in this process.

Further studies focusing on the correlation between educational philosophies, curriculum design orientation and epistemological beliefs adopted by pre-service teachers will surely shed light on to the related literature. Especially future research, different variables that may mediate the relationship between educational philosophy preference and curriculum design orientation can be studied. The factors affecting pre-service teachers' curriculum design orientations can also be examined. Other researchers can discuss the pros and cons of the results of this study, so that knowledge about educational philosophy preference and curriculum design orientation develops further.

\section{References}

Aslan, C. (2017). Examining epistemological beliefs of teacher candidates according to various variables. Eurasian Journal of Educational Research, 16 (67), 37-50.

Aslan, S. (2018). Investigating the relation between educational philosophies adopted by prospective teachers and their teaching - learning conceptions. Pegem Journal of Education and Instruction, 8(2), 307 - 326, http://dx.doi.org/10.14527/pegegog.2018.013

Arslan, A. (2017). Felsefeye giriş (24. Baskı) [Introduction to Philosophy]. Ankara: BB101 Pub..

Balc1, A., \& Küçükoğlu, A. (2019). Okul öncesi öğretmen ve öğretmen adaylarının eğitim inançları ve özyeterlik inançları üzerine bir inceleme [An Investigation on Educational Beliefs and Self-Efficacy Beliefs of Preschool Teachers and Teacher Candidates]. Kastamonu Education Journal, 27(3), 1123-1139. doi:10.24106/kefdergi.2712

Baş, G. (2013). Curriculum Design Orientations Preference Scale of Teachers: Validity and Reliability Study. Educational Sciences: Theory \& Practice, 13(2), 965 - 992.

Baş, G. (2015) Correlation Between Teachers' Philosophy of Education Beliefs and Their Teaching-Learning Conceptions. Education and Science, 40(182), 111-126.

Bas, G., \& Sentürk, C. (2019). Teachers' Educational Beliefs and Curriculum Orientations: A Relational Research. Teachers and Curriculum, 19(1), 45-53.

Belet, D. Ş., \& Güven, M. (2011). Sınıf öğretmeni adaylarının epistemolojik inançlarının ve bilişüstü stratejilerinin incelenmesi [Meta-cognitive strategy usage and epistemological beliefs of primary school teacher trainees]. Educational Sciences:Theory and Practice, 11, 31-57.

Berkant, H.G. (2020). Eğitimde Program Geliştirme: Kuramdan Uygulama Örnekleri [Curriculum development: Application Examples from Theory]. Ankara: An1 Pub..

Biçer, B., Er, H., \& Özel, A. (2013). Öğretmen adaylarının epistemolojik inançları ve benimsedikleri eğitim felsefeleri arasındaki ilişki [The relationship between the 
epistemological beliefs and educational philosophies of the teacher candidates adopted]. Journal of Theory \& Practice in Education (JTPE), 9(3), 31-57.

Bilgin, H., \& Aykac, N. (2016). Pre-Service teachers' teaching-learning conceptions and their attitudes towards teaching profession. Educational Process: International Journal, 5(2), 139-151.

Bingöl, U., \& Kinay, İ. (2018). Türkçe öğretmen adaylarının benimsedikleri eğitim felsefelerinin çeşitli değişkenlere göre değerlendirilmesi (Ziya Gökalp Eğitim Fakültesi örneği) [An investigation of educational phisolophies adopted by prospective Turkish teachers in terms of various variables]. Electronic Journal of Social Sciences, 17 (68), 1636-1647. . https://doi.org/10.17755/esosder.397519.

Bulut, İ., \& Arslan, S. (2010). İlköğretim 6. sınıf sosyal bilgiler dersi öğretim programının uygulamadaki etkililiğinin değerlendirilmesi [An evaluation of the primary education 6th grade social studies curriculum in practice]. In International Conference on New Trends in Education and Their Implications, Antalya (pp. 367-379).

Büyüköztürk. Ş. (2011). Soysal bilimler için veri analizi el kitabı [Handbook for social science data analysis], Ankara: Pegem Pub.

Büyüköztürk, Ş., Çokluk-Bökeoğlu, Ö. \& Şekercioğlu, G. (2012). Sosyal bilimler için çok değişkenli istatistik: SPSS ve LISREL uygulamaları [Multivariate statistics for social sciences: SPSS and LISREL applications]. Ankara: Pegem Pub.

Cevizci, A. (2015). Felsefe sözlüğ̈̈) [Philosophy Dictionary]. İstanbul: Say Pub.

Cheng, C., Y.(1994), Effectiveness of curriculum change in school: an organizational perspective, International Journal of Educational Management, Vol. 8 No. 3, pp. 2634. https://doi.org/10.1108/09513549410062416

Cheung, D. \& Ng, P.(2000). Science teachers' beliefs about curriculum design. Research in Science Education, 30, 357-375. https://doi.org/10.1007/BF02461556.

Cohen, J. (1988). Statistical power analysis for the behavioral sciences (2nd ed.). Hillsdale, NJ: Lawrence Erlbaum Associates

Çüçen, K. A. (2018). Felsefeye Giriş [Introduction to Philosophy]. Ankara: Sentez Pub.

Demirel, Ö. (2020). Eğitimde program geliştirme: Kuramdan uygulamaya (27. bs.) [Curriculum Development in Education: Theory to Practice]. Ankara: Pegem Pub.

Deryakulu, D. \& Büyüköztürk, Ş. (2005). Epistemolojik inanç ölçeği'nin faktör yapısının yeniden incelenmesi: Cinsiyet ve öğrenim görülen program türüne göre epistemolojik inançların karşılaştırılması [Re-examining the factor structure of the epistemological belief scale: Comparison of epistemological beliefs according to gender and the type of program studied]. Eurasian Journal of Educational Research, 18, 57-70.

Doğanay, A. (2011). Hizmet öncesi öğretmen eğitiminin öğretmen adaylarının felsefi bakış açılarına etkisi [The Effect of Pre-Service Teacher Education on the Educational Philosophies of Prospective Teachers]. Education \& Science, 36, 333-348.

Doğanay, A., \& Sarı, M. (2018). Effect of undergraduate education on the educational philosophies of prospective teachers: A longitudinal study. International Journal of Curriculum and Instructional Studies, 8(1), 01-22. https://doi.org/10.31704/ijocis.2018.001

D'souza, M. O. (1992). Philosophy, philosophy of education and the education of teachers. Interchange, 23 (3), 255-264

Dursun Sürmeli, Z \& Ünver, G. (2017). The relationship between mathematics achievement, self-regulated learning strategies, epistemological beliefs and academic self-concept. Turkish Journal of Computer and Mathematics Education (TURCOMAT), 8 (1), 83 102. DOI: 10.16949/turkbilmat.298393

Erdamar, G. \& Alpan, G. (2015). Öğretmen adaylarının epistemolojik inançlarının ve problem çözme yeteneklerinin gelişimi: Boylamsal bir çalışma [Development of 
Epistemological Beliefs and Problem Solving Skills of Student Teachers: A Longitudinal Study]. Journal of Turkish Educational Sciences, 13 (2), 77-91.

Ertürk, S. (1988). Türkiye'de eğitim felsefesi sorunu [Philosophy of education problems in Turkey]. H. U. Journal of Education, 3(3).

Ertürk, S. (2013). Eğitimde program geliştirme [Curriculum Development in Education]. Ankara: Edge Akademi.

Field, A. P. (2016).Discovering statistics: The reality enigma. SAGE Pub..

Flores, M.A., and Day, C. (2006). Context which shape and reshape new teachers' identities: a Multiperspective Study. Teaching and Teacher Education, 22 (2), 219-232.

Han, Ç. (2013). Öğretmenlerin işlevsel paradigmaları ve eğitim reform [Teachers' functional paradigms and educational reform]. Trakya University Journal of Education, 3(1), 5979.

Hayes, A., F. (2009) Beyond Baron and Kenny: Statistical mediation analysis in the new millennium. Communication Monographs, 76:4, 408-420, https://doi.org/10.1080/03637750903310360

Hayırsever, F. \& Oğuz, E. (2017). Öğretmen adaylarının eğitim inançlarının eleştirel düşünme eğilimlerine etkisi.[Effects of teacher candidates' educational beliefs on their critical thinking tendencies]. Abant Izzet Baysal University Journal of Faculty of Education, 17 (2), 757-778

Hofer, B. K. (2001). Personal epistemology research: Implications for learning and teaching. Journal of Educational Psychology Review, 13 (4), 353-383.

Hooper, D., Coughlan, J. \& Mullen, M. (2008), Structural equation modelling: Guidelines for determining model fit. Electronic Journal of Business Research Methods, 6(1), 53-60.

İra, N. \& Geçer K.A. (2017). Üniversite öğrencilerinin web ortamında bilgi arama ve yorumlama stratejileri ile epistemolojik inançları arasındaki ilişki [The Relationship between the University Students' Information Searching and Evaluative Strategies in Web-Based Environments and Their Epistemological Commitments]. E-International Journal of Educational Research, 8(2), 58-74.

Jenkins, G. (2020). Teacher agency: The effects of active and passive responses to curriculum change. Aust. Educ. Res. 47, 167-181. https://doi.org/10.1007/s13384-019-00334-2

Kanadlı, S. \& Akbaş A. (2019). Fen bilgisi öğretmen adaylarının epistemolojik inançları, öğrenme yaklaşımları ve LYS puanları arasındaki ilişkiler [The Relationship between Pre-services Science Teachers' Epistemological Beliefs, Learning Approaches and UPE Scores]. Mersin University Journal of the Faculty of Education, 11(1), 116-131.

Karaman, P. \& Bakaç, E . (2018). Öğretmenlerin eğitim programı yaklaşımı tercihlerinin çeşitli değişkenler açısından incelenmesi [Invastigating the teachers' curriculum orientations in terms of various variables]. Abant Izzet Baysal University Journal of Faculty of Education, 18 (1), 304-320. https://doi.org/10.17240/aibuefd.2018..-364651

Karasar, N. (2013). Bilimsel araştırma yöntemi [Scientific Researh Method]. Ankara: Nobel Pub.

Kaya, E., \& Ekici, M. (2017). Sosyal bilgiler öğretmenlerinin epistemolojik inançları ve öğretim stillerinin çeşitli değişkenler açısından incelenmesi [An Analysis of Social Studies Teachers' Epistemological Beliefs and Teaching Styles in terms of Several Variables]. Elementary Education Online, 16(2), 782-813.

Kozikoğlu, İ. \& Erden, R. Z. (2018). Öğretmen adaylarının eğitim felsefesi inançları ile eleştirel pedagojiye ilişsin görüşleri arasındaki ilişkinin incelenmesi [The Investigation of the Relationship between Pre-Service Teachers' Opinions Concerning Critical Pedagogy and Beliefs of Educational Philosophies]. Elementary Education Online, 17(3), 1566-1582. https://doi.org/10.17051/ilkonline.2018.466392 
Kozikoğlu, İ. \& Uygun, N. (2018). Investigation of the relationship between teachers' philosophies of education beliefs and curriculum design approaches. Çukurova University. Journal of Faculty of Education, 47 (2), 411- 438.

Kumral, O. (2015). Öğretmen adaylarının eğitim felsefeleri: Pamukkale Üniversitesi Eğitim Fakültesi Örneği [Student Teachers' Philosophy of Education: Case of Pamukkale University Faculty of Education]. HAYEF Journal of Education, 12 (2), 59-68.

Kürşad, M. Ş. (2015). Bilimsel araştırmaya yönelik tutum ve epistemolojik inanç arasındaki ilişkinin incelenmesi [Investigation of Relationship Between Attitude Toward Scientific Research and Epistemological Belief]. Abant Izzet Baysal University Journal of Faculty of Education, 15(2), 217 - 246.

Lane, R. (2015). Experienced geography teachers' PCK of students' ideas and beliefs about learning and teaching. International Research in Geographical and Environmental Education, 24:1, 43-57, DOI: 10.1080/10382046.2014.967113

Marsh, H.W., Balla, J.R. \& McDonald, R.P. (1988). Goodness-of-fit indexes in confirmatory factor analysis: The effect of sample size. Psychological Bulletin, 103, 391-410.

Moser, P. K. (2020). Bibliography on epistemology. (Trans: H. Y. Başdemir, N. Mehdiyev). P. K. Moser (Ed). in The Oxford handbook of epistemology (p. 569-587). Ankara: Adres Pub.

Olson, J. (1981) Teacher influence in the classroom: A context for understanding curriculum translation. InstrSci, 10, 259-275. https://doi.org/10.1007/BF00139803

Ornstein, A. C., \& Hunkin, F. P. (2014). Curriculum: Foundations, principles and issues. Harlow : Pearson Pub.

Özemre, A. Y. (2011). Epistemolojinin tanımı ve işlevi [Definition and function of epistemology]. N. Mehdiyev (Ed.). in Çağdaş epistemolojiye giriş [Introduction to contemporary epistemology] (p. 222-226). İstanbul: İnsan Pub.

Pajares, M. F. (1992). Teachers' beliefs and educational research: Cleaning up a messay construct. Review of Educational Research, 62 (3), 307-332.

Schommer, M. (1990). Effects of beliefs about the nature of knowledge on comprehension. Journal of Educational Psychology, 82(3), 498-504.

Schumacher, R. E., \& Lomax, R. G. (2010). A beginner's guide to structural equation modeling (3rd ed.). New York, NY: Routledge Pub..

Segall, W. E., \& Wilson, A. V. (2004). Introduction to education: Teaching in a diverse society. Rowman \& Littlefield.

Sönmez, V. (2009) Öğretmen elkitabı [Teachers Handbook]. Ankara: An1 Pub.

Sümer, N. (2000). Yapısal Eşitlik Modelleri: Temel Kavramlar ve Örnek Uygulamalar [Structural Equation Modeling: Basic Concepts and Aplications]. Turkish Psychological Articles, 3 (6), 49-74.

Şeker.H. (2019). Ĕ̈itimde Program Geliştirme Kavramlar Yaklaşımlar [Curriculum Development in Education - Concepts, Approaches]. Ankara: An1 Pub.

Şekercioğlu, A., G. \& Yıldırır, H., E. (2018). Eğitim fakültesi öğrencilerinin epistemolojik inançlarının bazı değişkenlere göre incelenmesi [Examination of The Epistemological Beliefs of The Teacher Candidates According to Some Variables]. Necatibey Faculty of Education Electronic Journal of Science and Mathematics Education. 12(1), 205227.

Terzi, A. R., \& Uyangör, N. (2017). An Analysis of the Relationship between Scientific Epistemological Beliefs and Educational Philosophies: A Research on Formation Teacher Candidates. Universal Journal of Educational Research, 5(12), 2171-2177.

Tezci, E., Erdener, M., A. \& Satıc1, S. (2016) The Effect of Pre-service Teachers' Epistemological Beliefs on Teaching Approaches. Universal Journal of Educational Research, 4(12A), 205-215, DOI: 10.13189/ujer.2016.041326 
Tezci, E. Uysal, A. (2004). Eğitim teknolojisinin gelişmesine epistemolojik yaklaşımların etkisi [The effect of epistemological approaches to the development of educational technology]. The Turkish Online Journal of Educational Technology, 3(2),158-164.

Turkan, A., Aydın, H. \& Üner, S. (2015). Öğretmen adaylarının çok kültürlü eğitim tutumları ile epistemolojik inançları arasındaki ilişkinin incelenmesi [The Relationship between Teacher Candidates' Attitudes towards Multicultural Education and Their Epistemological Beliefs]. Elementary Education Online, 1 (1), DOI: 10.17051/io.2016.16818

Ünsal, S. \& Korkmaz, F.(2017). Eğitim Programı Tasarımı Tercihlerine Yönelik Öğretmen Görüşleri [Teachers' Views On Their Preferences Regarding Curriculum Design Orientation]. Mersin University Journal of the Faculty of Education, 13 (1), 275-289. DOI: $10.17860 /$ mersinefd.305977

Uyangör, N., Şahan, H.,H., Atıc1, S. \& Börekci, C. (2016). An analysis of educational philosophies and teacher competencies. International Journal of Current Research, 8 (04), $30100-30106$.

Yazıcı, S. (2016). Felsefeye giriş (6. Baskl) [Introduction to Philosophy - 6.th Edition] İstanbul: Yeni İnsan Pub.

Yenice, N. (2015). An analysis of science student teachers' epistemological beliefs and metacognitive perceptions about the nature of science. Educational Sciences: Theory and Practice, 15 (6), 1623-1636.

Y1lmaz, E. (2017). Relationships between educational philosophies favoured by prospective teachers and their achievement motivation. Bartın University Journal of Faculty of Education, 6 (3), 1420-1429.

Yılmaz, V. \& Çelik, E. (2009). Yapısal Eşitlik Modellemesi [Structural Equation Modelling], Ankara: Pegem Pub. 